Egyptian Journal of Aquatic Biology \& Fisheries

Zoology Department, Faculty of Science,

Ain Shams University, Cairo, Egypt.

ISSN $1110-6131$

Vol. 24(3): 425 - 438 (2020)

www.ejabf.journals.ekb.eg

\title{
Nitrogen and protein contents of Ulva fasciata and Corallina officinalis under environmental variations.
}

\author{
Wagdy Labib and Shimaa Hosny* \\ National Institute of Oceanography and Fisheries, Alexandria, Egypt. \\ *Corresponding Author: Shimaasea@yahoo.com
}

\section{ARTICLE INFO \\ Article History: \\ Received: April 20, 2020 \\ Accepted: May 25, 2020 \\ Online: May 29, 2020}

Keywords:

Nitrogen;

Protein;

Ulva fasciata;

Corallina officinalis;

Conversion factor.

\begin{abstract}
The study estimates temporal and regional variations of nitrogen and protein content of the green algae Ulva fasciata and the red Corallina officinalis collected at three sites of the different entities along the Alexandria coast. The heterogeneity in environmental conditions contributes significantly on the variation of the algal nitrogen and protein contents. However, the varied storage of nitrogen by the algae cannot be directly linked to the ambient dissolved inorganic nitrogen concentrations. Ulva fasciata can accumulate higher concentrations than Corallina officinalis. The study suggests a new nitrogen-protein conversion factor to be applied for each species. A comparison with other published data is discussed.
\end{abstract}

\section{INTRODUCTION}

The fundamental role of nitrogen and protein in physiology and ecology of seaweeds has been a key research topic for decades (Boland $\boldsymbol{e t}$ al., 2012; Angell $\boldsymbol{e}$ t al., 2015). Algae for its nutritional importance are ideal candidate for human and animal nutrition and fish feed (Tabarsa et al., 2012; Kasimala et al., 2015). Genus Ulva has been intensively investigated to fully exploit its nutritive value (Labib et al., 2015b), while studies on Corallina, probably for its calcareous nature are rather limited (De Rosa et al., 2003). Among reasonable factors which explain differences in algal contents are taxonomic traits and algal morphology (Pedersen and Borum, 1996), species-specific ability in taking up dissolved nutrients (Martínez-Aragón et al., 2002), environmental conditions (Lourenco et al., 2005), and algal surface to biomass ratio (Lilliesköld-Sjöö and Mörk, 2009). Ulva and Corallina species are widely spread along Alexandria coast as obvious feature of algal diversity (Labib et al., 2015a; Hosny, 2016).

This study estimates variation in nitrogen and protein budget of the wild green algae $U$. fasciata Delile and the red C. officinalis Linnaeus that were collected during an annual cycle at three sites off Alexandria coast. Monitoring these contents in algae provides additional information that might be destined towards different applications as nutrient removal strategies to improve the health and stability of marine ecosystems, fertilizers and biofuel production, 
detection of eutrophication potential, and to establish new nitrogen-to-protein conversion factors for wild species.

\section{MATERIALS AND METHODS}

The three selected sites along Alexandria coast (Fig. 1) are characterized by different ecological characteristics. While, Abu Qir site has limited sewage input suggesting episodic anthropogenic influences at best, both Qaitbey and Sidi Gaber sites experience a high degree of environmental pressure; the first site is more vulnerable to stress. The waterborne nutrients discharge mainly from Mex Bay and Qaitbey area at the west and via small sewers at Abou Qir as well.

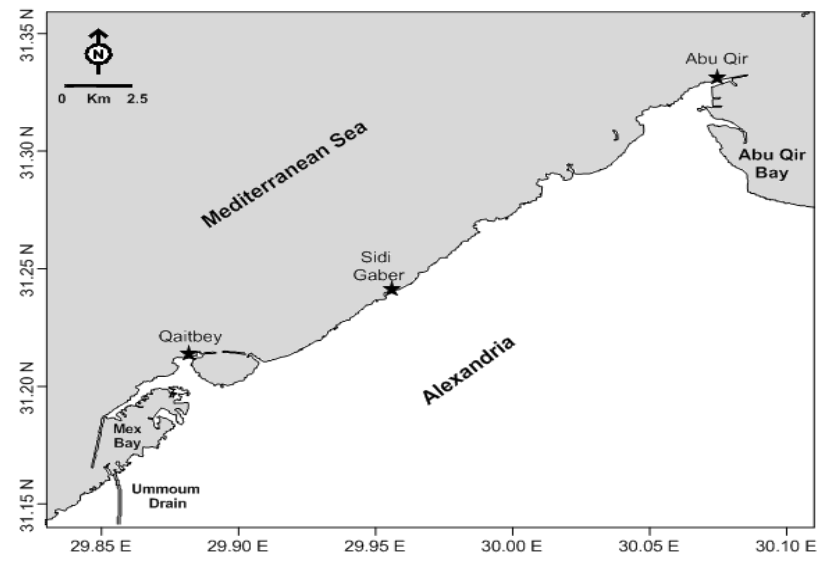

Figure 1. The study area and sampling stations

\section{Physical and chemical parameters}

Using the hydro lab. (HANA, Model HI 9828- USA), the measured field parameters were water temperature, salinity, dissolved oxygen, and $\mathrm{pH}$. Determination of dissolved inorganic nutrient concentrations follows Strickland and Parsons (1972).

\section{Thallus analyses}

The taxonomic keys of Abbott and Hollenberg (1976) and Aleem (1993) were consulted for algal identification. At least 3 whole plants of each species were collected from each sampling site, washed with seawater, placed in plastic bags, and kept on ice until quick return to the laboratory. In the laboratory, samples were gently brushed under running seawater, rinsed with distilled water, and dried at $60^{\circ} \mathrm{C}$ for at least three days until constant weight. The dried material was ground into a powder and kept in desiccators containing silica-gel at room temperature until $\mathrm{N}$ and $\mathrm{P}$ tissue analyses.

\section{Determination of total nitrogen content}

Using Hach digestor (Digesdhal R@, Hach Co.), the total nitrogen was determined spectrophotometrically (Shimadzu UV-150-02 spectrophotometer) after peroxymonosulphuric acid digestion (Hach et al., 1987; Lourenco et al., 2005). For each species, three measurements of nitrogen from different parts were performed. 
Nitrogen content was calculated as \% nitrogen $=[14: 01 \mathrm{X}(\mathrm{ml}$ titrant for sample- $\mathrm{ml}$ titrant for blank) X molarity of acid] / weight of sample X 100.

\section{Determination of total soluble protein content}

The total soluble protein content $\left(\mathrm{mg} \mathrm{mL}^{-1}\right)$ in the seaweed samples was determined using Shimadzu UV-150-02 spectrophotometer following the method of Bradford (1976). The determined total soluble protein concentration represents the mean of three replicates. The crude protein content was then calculated using different conversion factors to convert nitrogen to protein.

\section{Statistical analysis}

Pearson linear correlation test (significance level at $\mathrm{P}<0.05$ ) was applied to judge possible link between variations of nitrogen and protein contents and measured environmental factors.

\section{Results}

\section{Physico-chemical profiles}

A descriptive summary of the measured physico-chemical parameters is given in Table 1 . Water temperature demonstrates strong seasonality. A weak regional temperature variation was observed during cool winter $\left(\Delta \mathrm{T} 0.09-0.64^{\circ} \mathrm{C}\right)$. The spring warming by April raised temperature by about $2-5^{\circ} \mathrm{C}$, and it reached maximum in summer. The sharp drop in autumn was obvious in November. Salinity exhibits considerable temporal and regional variations with no seasonality and a tendency for an increase towards the east was observed. Conversely in temperature seasonal pattern, salinity was rather higher in winter and autumn. The $\mathrm{pH}$ values were always in the alkaline side and with limited variation $(\Delta \mathrm{pH}=0.4-0.9)$. Dissolved nutrients exhibit an erratic distribution over time. The relatively higher concentrations, particularly at Qaitbey are consistent with arrival of continuous supply and /or pulses of discharged waters, mainly during summer experiencing symptoms of eutrophication. However, almost unchangeable concentrations were also detected intermittently at Sidi Gaber and Qaitbey sites. The supply of nutrients at Abou Qir is likely to be episodic. Seasonally, the nutrients trend shows highest concentrations in summer, relatively lower in late winter and late spring and at minimum in late autumn, yet, no evidence of nitrogen and/or phosphorus-limitation was observed. Virtually the total dissolved inorganic nitrogen (DIN) was mostly in nitrate form (55.85-58.8\%), which peaked in August, February and May (5.02-8.9 $\mu \mathrm{M})$. Nitrite was rather less (average $2.5 \mu \mathrm{M}$ ), and ammonia had the lowest contribution of 8.78-24.02\%, and it was traced most of the time at Abou Qir. Meanwhile, ammonia concentration never exceeds $7.8 \mu \mathrm{M}$ (Qaitbey, August), and it showed a tendency to decrease from then on. All the nitrogen sources exhibited the same seasonal trend. Phosphate concentrations showed a decreasing trend towards the east of the study area, and with no particular seasonal trend. Its concentration varied in most of the observations between 0.22 and $1.41 \mu \mathrm{M}$, while, the high levels $(5.8-6.56 \mu \mathrm{M})$ were registered at Qaitbey in summer. Silicate concentrations, based on average value matched well the temporal pattern of dissolved inorganic phosphorous (DIP). The concentrations were $<\mathrm{I} \mu \mathrm{M}$ most of the year round, 
and varied considerably in summer when Sidi Gaber and Qaitbey sites sustained levels between 7.6-14.3 $\mu \mathrm{M}$. This was followed by a substantial reduction in autumn. The uneven input of discharged waters leads the inconsistency in the $\mathrm{N}: \mathrm{P}$ ratio (range $3.24-109.83 \mu \mathrm{M}$ ); the highest in winter and spring, and the lowest in summer. The N:P ratios above the normal Redfield ratio (16) accounted for one observation at Abou Qir and three others at the middle site, while the levels were always <16 at Qaitbey site.

Table 1: Descriptive summary of the measured physico-chemical parameters.

\begin{tabular}{|c|c|c|c|c|c|c|c|c|c|c|}
\hline \multirow[b]{2}{*}{ Mean } & Temperature & Salinity & $\mathrm{pH}$ & $\mathrm{NO}_{2}$ & $\mathrm{NO}_{3}$ & $\mathrm{NH}_{4}$ & Total $\mathrm{N}$ & $\mathrm{SiO}_{4}$ & $\mathrm{PO}_{4}$ & N/P ratio \\
\hline & 23.19 & 37.52 & 8.61 & 1.20 & 2.60 & 0.92 & 7.08 & 1.31 & 0.95 & 10.93 \\
\hline Standard Deviation & 4.41 & 0.92 & 0.32 & 0.32 & 1.95 & 1.34 & 2.14 & 1.79 & 0.80 & 6.28 \\
\hline Minimum & 17.63 & 36.12 & 8.11 & 1.20 & 1.30 & 0.09 & 2.77 & 0.12 & 0.31 & 3.39 \\
\hline Maximum & 29.37 & 38.65 & 9.00 & 3.02 & 5.68 & 4.16 & 12.86 & 4.68 & 2.44 & 23.49 \\
\hline Confidence Level (95.0\%) & 3.69 & 0.77 & 0.27 & 0.60 & 2.47 & 1.12 & 4.30 & 1.50 & 0.67 & 5.25 \\
\hline \multicolumn{11}{|l|}{ Sidi Gaber } \\
\hline \multirow[b]{2}{*}{ Mean } & Temperature & Salinity & $\mathrm{pH}$ & $\mathrm{NO}_{2}$ & $\mathrm{NO}_{3}$ & $\mathrm{NH}_{4}$ & Total $\mathrm{N}$ & $\mathrm{SiO}_{4}$ & $\mathrm{PO}_{4}$ & N/P ratio \\
\hline & 22.84 & 37.21 & 8.54 & 2.21 & 5.93 & 2.55 & 10.61 & 2.52 & 1.39 & 23.70 \\
\hline Standard Deviation & 4.40 & 1.08 & 0.20 & 0.90 & 2.99 & 2.28 & 6.18 & 3.61 & 1.89 & 35.51 \\
\hline Minimum & 18.00 & 36.00 & 8.22 & 1.08 & 1.96 & 0.08 & 3.82 & 0.08 & 0.12 & 3.24 \\
\hline Maximum & 29.24 & 38.90 & 8.93 & 3.40 & 9.35 & 5.55 & 19.27 & 9.01 & 5.74 & 109.83 \\
\hline Confidence Level (95.0\%) & 3.68 & 0.91 & 0.17 & 0.75 & 2.50 & 1.90 & 5.16 & 3.02 & 1.58 & 29.68 \\
\hline \multicolumn{11}{|l|}{ Qaitbey } \\
\hline \multirow[b]{2}{*}{ Mean } & Temperature & Salinity & $\mathrm{pH}$ & $\mathrm{NO}_{2}$ & $\mathrm{NO}_{3}$ & $\mathrm{NH}_{4}$ & Total N & $\mathrm{SiO}_{4}$ & $\mathrm{PO}_{4}$ & N/P ratio \\
\hline & 22.41 & 36.55 & 8.43 & 2.34 & 7.11 & 3.35 & 12.44 & 3.87 & 2.26 & 8.46 \\
\hline Standard Deviation & 4.22 & 1.08 & 0.14 & 1.48 & 3.14 & 2.75 & 7.27 & 5.98 & 2.45 & 4.57 \\
\hline Minimum & 17.86 & 35.04 & 8.23 & 0.56 & 2.80 & 0.15 & 3.69 & 0.37 & 0.34 & 3.41 \\
\hline Maximum & 28.83 & 37.56 & 8.65 & 4.90 & 11.68 & 7.80 & 24.87 & 14.30 & 6.56 & 15.88 \\
\hline Confidence Level (95.0\%) & 3.53 & 0.90 & 0.12 & 1.24 & 2.63 & 2.30 & 6.08 & 5.00 & 2.05 & 3.82 \\
\hline
\end{tabular}

\section{Nitrogen and protein content}

The monthly quantification of nitrogen and protein content is shown in Figure 2. The nitrogen content of $U$. fasciata and $C$. officinalis differed in regional and seasonal scales and among species, showing no particular cyclic pattern. The nitrogen contents of $U$. fasciata were always higher than those of $C$. officinalis estimated by about 2.36, 3.72 and 3.51-fold increase at Abou Qir, Sidi Gaber and Qaitbey, respectively, however, an exceptional case of a reverse trend was observed at the first site in July. The seasonal trend showed the minimum concentration in both species to be registered to November and the maximum in spring and summer. Regionally, based on average values, the concentrations of $U$. fasciata were almost equal at Qaitbey and Sidi Gaber, and showed a slight decrease towards the east, while, C. officinalis exhibited a reverse trend. Descriptive analyses of nitrogen $\%$ and protein $\%$ at the sites is given in Table 2 . The protein content showed considerable temporal variations among the sites and species and generally goes in parallel to the nitrogen content trend. Ulva fasciata showed much higher protein than C. officinalis; however, its levels at Abou Qir did not match well with those of the nitrogen particularly in June and October. The protein contents at Qaitbey were relatively higher when compared with the other two sites, and based on average values; this increase was estimated as $15 \%$ and $18 \%$ at Abou Qir and Sidi Gaber. Ulva fasciata possessed a protein level that reaches maximum in April and July at Sidi Gaber and Qaitbey, respectively. The protein content of $C$. officinalis in most cases was characterized by a narrow range of variation (2.21- 
$2.95 \%, 0.17-0.18 \mathrm{~g} / \mathrm{g})$, and it was relatively higher in June $(3.24 \%, 0.27 \mathrm{~g} / \mathrm{g})$. Generally, the protein content of $C$. officinalis followed the same temporal and regional trend of $U$.fasciata.
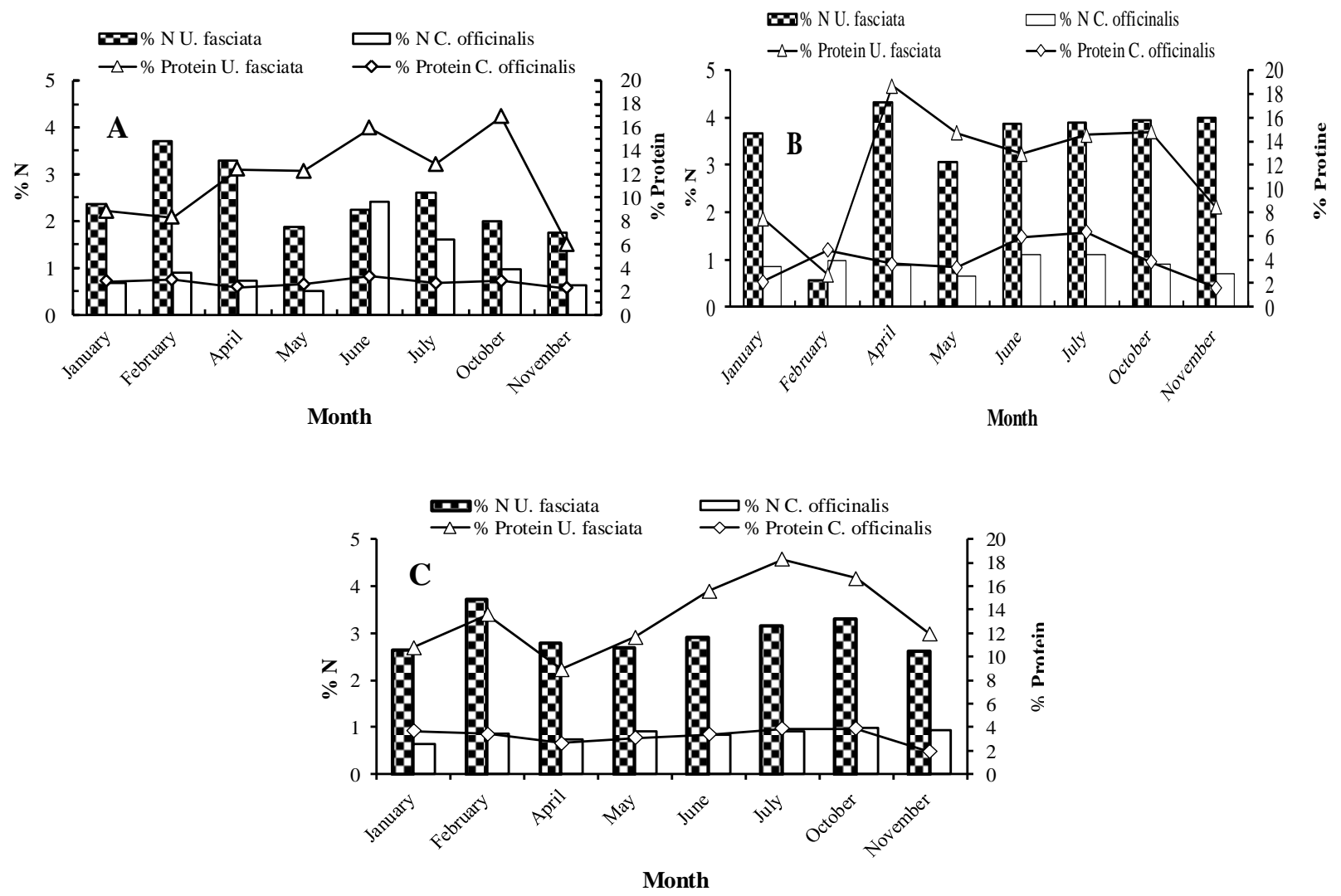

Fig. 2: Temporal nitrogen and protein percent (A: Abou Qir, B: Sidi Gaber, C: Qaitbey).

Table 2: Descriptive analyses of nitrogen and protein percent.

\begin{tabular}{|c|c|c|c|c|c|c|c|c|c|}
\hline \multirow[t]{2}{*}{ Abou Qir } & \multirow{2}{*}{$\begin{array}{c}\% \mathrm{~N} \\
\text { U.fasciata }\end{array}$} & \multirow{2}{*}{$\frac{\% \mathrm{~N}}{\text { C. officinalis }}$} & \multirow{2}{*}{$\begin{array}{l}\% \text { Protein } \\
\text { U. fasciata }\end{array}$} & \multirow{2}{*}{$\begin{array}{l}\% \text { Protein } \\
\text { C. officinalis }\end{array}$} & \multirow[t]{2}{*}{ Sidi Gaber } & \multicolumn{2}{|c|}{$\% \mathrm{~N}$} & \multicolumn{2}{|c|}{$\%$ Protein } \\
\hline & & & & & & U. fasciata & C. officinalis & U. fasciata & C. officinalis \\
\hline Mean & 2.48 & 1.05 & 11.68 & 2.71 & Mean & 3.41 & 0.90 & 11.79 & 3.93 \\
\hline Standard Deviation & 0.65 & 0.60 & 3.54 & 0.32 & Standard Deviation & 1.21 & 0.16 & 5.14 & 1.67 \\
\hline Sample Variance & 0.42 & 0.37 & 12.52 & 0.10 & Sample Variance & 1.47 & 0.03 & 26.43 & 2.78 \\
\hline Minimum & 1.75 & 0.62 & 5.94 & 2.21 & Minimum & 0.55 & 0.66 & 2.75 & 1.60 \\
\hline Maximum & 3.70 & 2.42 & 16.92 & 3.24 & Maximum & 4.33 & 1.10 & 18.67 & 6.29 \\
\hline Confidence Level $(95.0 \%)$ & 0.50 & 0.46 & 2.72 & 0.24 & Confidence Level $(95.0 \%)$ & 1.01 & 0.13 & 4.30 & 1.39 \\
\hline
\end{tabular}

\begin{tabular}{|l|c|c|c|c|}
\hline \multirow{2}{*}{ Qaitbey } & \multicolumn{2}{|c|}{$\% \mathrm{~N}$} & \multicolumn{2}{c|}{ \% Protein } \\
\cline { 2 - 5 } & U.fasciata & C. officinalis & U. fasciata & C. officinalis \\
\hline Mean & 2.97 & 0.85 & 13.43 & 3.22 \\
\hline Standard Deviation & 0.39 & 0.11 & 3.20 & 0.67 \\
\hline Sample Variance & 0.15 & 0.01 & 10.22 & 0.45 \\
\hline Minimum & 2.60 & 0.63 & 8.93 & 1.91 \\
\hline Maximum & 3.70 & 0.97 & 18.32 & 3.87 \\
\hline Confidence Level (95.0\%) & 0.32 & 0.09 & 2.67 & 0.56 \\
\hline
\end{tabular}




\section{Discussion}

Ulva and Corallina species exhibited a wide regional range of appearance throughout the study period, confirming their ability to tolerate a broad range of heterogeneous environmental conditions Williamson et al. (2017), which made essential contribution to the seasonal variation of nitrogen and protein contents. The results of the correlation matrix (Table 3) might be tentative and contradicted for the effect of the same variable. This was clear regarding the effect of temperature and salinity, which explains at Abou Qir insignificant negative correlation with the nitrogen content of $U$. fasciata, but, these parameters were considered among the majors affecting variables controlling the temporal variations in nitrogen content of $C$. officinalis. Temperature is likely a large source of stress (Lin and Hung, 2004), however, conflicted data about its effect on growth rate of cultivated Ulva and Coralline algae were reported (Martin $\boldsymbol{e t}$ al., 2007 and Bradley et al., 2018). Moreover, the $\mathrm{pH}$ variability, despite its limited range, might explain such contradictory as showing significantly correlation with Ulva nitrogen.

\section{Algal nitrogen content}

The study evaluated the changed nutrients key environmental factors that strongly influence the nitrogen content of $C$. officinalis rather than $U$. fasciata. Since nutrient concentrations at Qaitbey were always high, the matrix analyses failed to define its specific contribution on nitrogen content. However, the combination of $\mathrm{pH}, \mathrm{NO}_{2}$ and $\mathrm{NO}_{3}$ explains $36 \%$ of the nitrogen variability in Ulva, while, temperature, salinity, $\mathrm{NO}_{2}$ and nitrogen to phosphorous ratio (N/P) together explain $68 \%$ in Corallina. The N/P ratio as an important factor favors algal growth and bloom development (Granéli et al., 2008) contributes greatly on nitrogen content of $C$. officinalis (negative correlation).

Table 3: Correlation matrix between nitrogen content (\%) and physico-chemical parameters.

\begin{tabular}{|c|c|c|c|c|c|c|c|c|c|c|c|c|c|}
\hline & Temperature & Salinity & pH & $\mathrm{NO}_{2}$ & $\mathrm{NO}_{3}$ & $\mathbf{N H}_{4}$ & Total N & $\mathrm{SiO}_{4}$ & $\mathrm{PO}_{4}$ & N/P ratio & $\mathrm{NO}_{2} / \mathrm{TN}$ & $\mathrm{NO}_{3} / \mathrm{TN}$ & $\mathrm{NH}_{4} / \mathrm{TN}$ \\
\hline \multicolumn{14}{|l|}{ Abou Qir } \\
\hline U. fasciata & -0.28 & -0.14 & 0.53 & 0.37 & 0.32 & 0.21 & 0.33 & -0.01 & -0.16 & 0.78 & -0.32 & 0.21 & 0.25 \\
\hline C. officinalis & 0.73 & -0.84 & -0.20 & 0.29 & 0.74 & 0.41 & 0.65 & 0.86 & 0.95 & -0.40 & -0.66 & 0.59 & 0.30 \\
\hline \multicolumn{14}{|l|}{ Sidi Gaber } \\
\hline U. fasciata & $\mathbf{0 . 3 3}$ & -0.73 & -0.82 & 0.25 & 0.67 & 0.66 & 0.63 & 0.43 & 0.40 & -0.17 & -0.77 & 0.07 & 0.71 \\
\hline C. officinalis & 0.49 & -0.46 & -0.85 & 0.50 & 0.54 & 0.58 & 0.57 & 0.74 & 0.75 & -0.68 & -0.40 & -0.09 & 0.44 \\
\hline \multicolumn{14}{|l|}{ Qaitbey } \\
\hline U. fasciata & 0.04 & 0.01 & 0.46 & 0.30 & 0.46 & 0.19 & 0.35 & 0.12 & 0.16 & -0.06 & -0.14 & -0.01 & 0.15 \\
\hline C. officinalis & 0.41 & -0.34 & -0.07 & -0.33 & 0.26 & 0.19 & 0.12 & 0.14 & 0.21 & -0.72 & -0.80 & 0.60 & 0.28 \\
\hline
\end{tabular}

Even distinct variation was detected in time and space of the algal nitrogen concentrations, in accordance with Hernández et al. (1997) it is hard to define specific pattern of seasonal variation as a consequence of the nutrient input. Generally, the relatively higher nitrogen contents in $U$. fasciata are in contradiction with (Lourenço, 2002; Diniz et al. 2011) that thalli of red algae tend to show higher nitrogen concentrations than green and brown algae for the presence of phycoerithrin (Lobban and Harrison, 1994). Comparing with other previously published data, the maximum nitrogen content in $U$. fasciata is almost similar to that found for the same species at Qaitbey area (Moustafa and Saeed, 2014), but it lies within the range of the others Ulva lactuca, U. capensis and U. rigida (0.71- $8.33 \%)$ that were reported by Lourenço et 
al. (2004) and Shuuluka et al. (2013). To our available knowledge, there is little information about nitrogen content of $C$. officinalis. However, its present maximum content is greater than that of Corallina elongata (Safinaz and Ragaa, 2013). Regionally, Ulva and Corallina species were able to reflect ambient nitrogen gradients as proved from its higher nitrogen levels at Qaitbey when compared with Abou Qir site (up to 1.22 folds). However, the study cannot definite specific relation between nitrogen content and nutrient concentrations i.e a typical positive linear trend is not exist. Yet, the lowest nitrogen concentrations in response to the noticeable drop in seawater nutrients and its reverse trend accompanied nutrient enrichment of different degrees might explain even partially such relation. Furthermore, the observed nitrogen content of $U$. fasciata in February, April, June, July and October also might offer some evidences to the non-existed association. Thus, it is important to emphasize that the correspondence between the concentrations of seawater inorganic nitrogen and the nitrogen content of the present tested algae at the studied area is relatively far from precise, and the storage of nitrogen by the seaweeds cannot be directly linked to the absolute concentration of dissolved inorganic nitrogen in water, either in linear (Fong et al., 1994) or hyperbolic relationship (Cohen and Neori, 1991). The present data documented a reliable potential detector not only for current nutrient availability, but for relative nutrient loading and pulses at a shorthistory. Thus, the study suggests algal nitrogen content a useful bioindicator in eutrophic regions of Alexandria where nutrient turnover in the water column is rapid, superior to traditional water sampling in some cases (Lourenço et al., 2006; Kim et al., 2014).

The levels below $2 \%$ of nitrogen content in Ulva were found exclusively during May and November at Abou Qir, while the other values in the whole study varied between 2.1 and 3.9\%. These results indicate nitrogen contents are equal and/or just above the critical nitrogen concentrations $(2.2 \%)$ which has been defined as the minimum percentage tissue nitrogen level that saturates growth rate for optimal growth Hernandez et al. (2005). However, the threshold value of the internal nitrogen concentration necessary to maintain maximum growth (critical concentration) of Ulva spp. is a species-specific trait (Pedersen and Borum, 1996), and it may vary between 1.1 and $3.2 \%$ d.w depending on nitrogen source, and a level below $\sim 1 \%$ was proved to cease the growth of Ulva rigida (Fujita et al., 1989; Villares and Carballeira, 2003). Thus, the levels of tissue nitrogen in $U$. fasciata suggest enough nitrogen for the species to face division, even in periods when lower percentages of algal nitrogen contents were measured.

\section{Protein content}

Among the physical parameters, temperature seems significantly correlated with the protein content of $U$. fasciata at Qaitbey, and salinity for the two species at the other sites (Table 4). However, the relatively high protein in cool winter characterized by nutrient enrichment may be attributed to luxury accumulation of nitrogen with expected drop in growth rates over winter. The results seem similar to that observed for $U$. lactuca Shuuluka et al., (2013). The data stresses the significant linkage between inorganic nitrogen sources and the seasonal variation of protein (Neill et al., 2003); it was more obvious at Abou Qir and Sidi Gaber and the effect of $\mathrm{SiO}_{4}$ and $\mathrm{PO}_{4}$ (Cronin and Hay, 1996) was stronger at Qaitbey. Except for the significant 
contribution of N/P ratio with the protein of $U$. fasciata at Qaitbey, this ratio was of a negligible effect at the other sites. The matrix correlation showed different significant correlation between the protein content of $U$. fasciata and $C$. officinalis at Sidi Gaber $(\mathrm{r}=-0.77$ and 0.85, respectively), and for $C$. officinalis at Abou Qir as well $(r=-0$. 67). The observed negative correlation was reported for many types of seaweed which characterize by high storage capacity to excess nitrogen during luxury consumption Taylor et al. (2003). Referring published data, a wide variation of the protein content in $U$. fasciata is reported (Table 5). The protein content of C. officinalis is typically similar to the previous record of Ismail (2017), but it is lower than level $8.2 \%$ determined by Fathy (2007). Ramos et al. (2000) reported a very low level (2.30\% dw), probably attributed to its calcareous nature.

Table 4: Correlation matrix between protein content $(\%)$ and physico-chemical parameters.

\begin{tabular}{|c|c|c|c|c|c|c|c|c|c|c|c|c|c|}
\hline$\%$ Protein & Temperature & Salinity & pH & $\mathrm{NO}_{2}$ & $\mathrm{NO}_{3}$ & $\mathrm{NH}_{4}$ & $\begin{array}{c}\text { Total } \\
\mathbf{N}\end{array}$ & $\mathrm{SiO}_{4}$ & $\mathrm{PO}_{4}$ & $\begin{array}{l}\text { N/P } \\
\text { ratio }\end{array}$ & $\begin{array}{c}\mathrm{NO}_{2} / \mathrm{T} \\
\mathbf{N} \\
\end{array}$ & $\begin{array}{c}\mathrm{NO}_{3} / \mathrm{T} \\
\mathbf{N} \\
\end{array}$ & $\mathrm{NH}_{4} / \mathrm{TN}$ \\
\hline \multicolumn{14}{|l|}{ Abou Qir } \\
\hline U. fasciata & 0.18 & -0.73 & -0.55 & 0.13 & 0.76 & 0.59 & 0.63 & 0.15 & 0.10 & 0.22 & -0.96 & 0.36 & 0.74 \\
\hline C. officinali. & 0.71 & -0.80 & -0.86 & 0.67 & 0.86 & 0.85 & 0.87 & 0.81 & 0.71 & -0.23 & -0.71 & -0.10 & 0.74 \\
\hline \multicolumn{14}{|l|}{ Sidi Gaber } \\
\hline U. fasciata & 0.18 & -0.73 & -0.55 & 0.13 & 0.76 & 0.59 & 0.63 & 0.15 & 0.10 & 0.22 & -0.96 & 0.36 & 0.74 \\
\hline C. officinali. & 0.71 & -0.80 & -0.86 & 0.67 & 0.86 & 0.85 & 0.87 & 0.81 & 0.71 & -0.23 & -0.71 & -0.10 & 0.74 \\
\hline \multicolumn{14}{|l|}{ Qaitbey } \\
\hline U.fasciata & 0.71 & -0.44 & -0.16 & 0.46 & 0.55 & 0.47 & 0.54 & 0.70 & 0.72 & -0.71 & -0.17 & -0.08 & 0.24 \\
\hline C. officinali. & 0.37 & -0.22 & 0.35 & 0.57 & 0.43 & 0.29 & 0.44 & 0.37 & 0.38 & 0.04 & 0.33 & -0.49 & 0.09 \\
\hline
\end{tabular}

Table 5: Percentage of protein content of Ulva fasciata.

\begin{tabular}{|c|c|c|}
\hline Species & $\%$ & Author \\
\hline \multirow[t]{15}{*}{ U. fasciata } & 9.46 & Present work \\
\hline & $1.03 \pm 0.1$ & Kaehler and Kennish (1996) \\
\hline & 6.26 & Ramos et al. (2000) \\
\hline & 12.3 & $\begin{array}{l}\text { McDermid and Stercke } \\
(2003)\end{array}$ \\
\hline & 13.3 & de Pádua et al . (2004) \\
\hline & 9.56 & Anitha et al. (2008) \\
\hline & $3.45 \pm 0.02$ & Pise and Sabale (2010) \\
\hline & 14.7 & Rameshkumar et al . (2012) \\
\hline & $17.08 \pm 1.19$ & Kokilam and Vasuki (2014) \\
\hline & 25.12 & Nascimento et al. (2014) \\
\hline & $14.98 \pm .09$ & Jayalakshmi et al. (2014) \\
\hline & 25.12 & Kailas and Nair (2015) \\
\hline & $20.6-32$ & Labib et al. (2015) \\
\hline & 9.56 & Ismail (2017) \\
\hline & $20.7-27.6$ & Moustafa and Eladel (2015) \\
\hline
\end{tabular}

\section{Nitrogen-to-protein conversion factor}

The conversion factor 6.25 is widely accepted to calculate protein as $\mathrm{N} \times 6.25$ (Jones, 1941), review by Angell et al. (2015). It is based on an assumption that the general nitrogen content in food proteins is $16 \%$ and all nitrogen is protein-bound. However, a wide range of other compounds called non-protein nitrogen contain varied nitrogen content of different proteins (Angell et al., 2015). There are potential inconsistencies using the nitrogen-to-protein conversion 
factor 6.25 (Kim et al., 2014). We report new nitrogen to-protein conversion factor for $U$. fasciata and C. officinalis taking into account month, site and environmental condition (Table 6). The calculated mean value of the conversion factor for $U$. fasciata varied between 3.6 and 4.52, while that of $C$. officinalis between 3.03 and 4.51. Angell et al. (2015) through analyses of 103 species of three phyla considering a range of nitrogen content determined an overall mean nitrogen-to-protein conversion factor of 4.76 and proposed overall median value of 5 to be the most accurate universal seaweed nitrogen-to-protein conversion factor. The present data declared distinct temporal and regional variations in the values of the conversion factor, but, with no common trend. Comparing our results with that calculated by the original and still frequently used conversion factor 6.25, there is over estimation of protein by 0.88-2.79 fold for $U$. fasciata, and 1.24-4.67 for C. officinalis at Abou Qir, 1.25-3.06 and 1.09-2.77 at Sidi Gaber, and 1.072.64 and 1.08-3.01 at Qaitbey for the two species, respectively. Overestimation for other Ulva species was determined by Marinho et al. (2017) as $64.1 \%$ in $U$. capensis, $77.1 \%$ in $U$. rigida and $58.9 \%$ in $U$. lactuca, and the authors suggested factors as 5.58, 5.12 and 5.65 for the three species respectively, and an average of 5.45 to estimate the protein content of the Ulva species.

Table 6: Nitrogen-to-protein conversion factor of Ulva fasciata and Corallina officinalis.

\begin{tabular}{|c|c|c|c|c|c|c|c|c|c|c|c|}
\hline \multicolumn{12}{|l|}{ Abou Qir } \\
\hline Species & January & February & April & May & June & July & October & November & Minimum & Maximum & Mean \\
\hline$U$. fasciata & 2.76 & 2.41 & 2.96 & 4.00 & 4.25 & 3.29 & 5.46 & 2.83 & 2.41 & 5.46 & 3.60 \\
\hline C. officinalis & 3.29 & 3.04 & 2.61 & 3.90 & 2.95 & 2.43 & 3.15 & 3.11 & 2.43 & 3.90 & 3.03 \\
\hline \multicolumn{12}{|l|}{ Sidi Gaber } \\
\hline Species & January & February & April & May & June & July & October & November & Minimum & Maximum & Mean \\
\hline U. fasciata & 2.04 & 5.01 & 4.31 & 4.80 & 3.35 & 3.73 & 3.76 & 2.11 & 2.11 & 5.01 & 3.87 \\
\hline C. officinalis & 2.45 & 4.94 & 4.08 & 5.02 & 5.36 & 5.72 & 4.16 & 2.26 & 2.26 & 5.72 & 4.51 \\
\hline \multicolumn{12}{|l|}{ Qaitbey } \\
\hline Species & January & February & April & May & June & July & October & November & Minimum & Maximum & Mean \\
\hline U. fasciata & 4.08 & 3.67 & 3.21 & 4.36 & 5.36 & 5.81 & 5.05 & 4.59 & 3.21 & 5.81 & 4.52 \\
\hline C. officinalis & 5.81 & 3.94 & 3.55 & 3.36 & 4.02 & 4.30 & 3.99 & 2.08 & 2.08 & 5.81 & 3.88 \\
\hline
\end{tabular}

\section{CONCLUSION}

The monthly quantification of tissue $\mathrm{N}$ and $\mathrm{P}$ content of $U$. fasciata and $C$. officinalis was investigated under the influence of a myriad of highly variable environmental conditions taking into account multiple geographic regions. The results revealed differed regional and seasonal variations and among species as well. The $\mathrm{N}$ contents of $U$. fasciata were always higher than those of $C$. officinalis by about 2.36-3.72 fold, and with no particular cyclic pattern as a consequence of continuous supply and/or pulses of high nutrient concentration input. We suggest tissue $\mathrm{N}$ content a useful bioindicator in eutrophic waters where nutrient turnover is rapid, superior to traditional water sampling in some cases. In conclusion, multiplying the nitrogen content by 6.25 cannot provide a sound estimate of the macroalgae protein content found in Alexandria waters, and it is important to develop more precise specific nitrogen-to-protein conversion factors. 


\section{REFERENCES}

Abbott, I. A. and Hollenberg, J. (1976). Marine Algae of California Stanford University Press; $827 \mathrm{pp}$.

Aleem, A. A. (1993). The marine algae of Alexandria, Egypt. University Alexandria, 139pp.

Angell, A. R.; Mata, L. R. de Nys and Paul, N. A. (2015). The protein content of seaweeds: a universal nitrogen-to protein conversion factor of five. J Appl Phycol., 28 (1):511-524.

Boland, M. J.; Rae, A. N.; Vereijken, J. M.; Meuwissen, M. P. M.; Fischer, A. R. H.; van Boekel, M. A. J. S.; Rutherfurd, S. M.; Gruppen, H.; Moughan, P. J. and Hendriks, W. H. (2012). The future supply of animal-derived protein for human consumption. Trends Food Sci. Technol., 29:62-73.

Bradford, M. M. (1976). A rapid and sensitive method for the quantitation of microgram quantities of protein utilizing the principle protein-dye binding. Anal. Biochem. 72(1): 248-254.

Bradley, A.; John Colt, G.; Maynard, D.; Ken Webb, B.; Ronald, B.; Johnson, G. S. and Richard, H. B. (2018). Intensive land-based production of red and green macroalgae for human consumption in the Pacific Northwest: an evaluation of seasonal growth, yield, nutritional composition, and contaminant levels. Alga., 33(1): 109-125.

Cohen and Neori (1991). Ulva lactuca Biofilters for Marine Fishpond Effluents. I. Ammonia Uptake Kinetics and Nitrogen Content. Bot. Mar., 34(6): 475-482.

Cronin, G. and Hay, M. E. (1996). Within-plant variation in seaweed palatibility and chemical defenses: optimal defense theory versus the growth-differentiation balance hypothesis. Oecologia, 105:361-368.

De Rosaa, S.; Kamenarska, Z.; Stefanov, K.; Konaklieva, S. D.; Najdenski, C. and Tzvetkova, I. (2003). Chemical Composition of Corallina mediterranea Areschoug and Corallina granifera Ell. et Soland. Zeitschrift für Naturforschung, 58: 325-332.

Diniz G. S.; Barbarin, E.; Oiano-Neto, J.; Pacheco, S. and Sergio O.; Lourenço (2011). Gross Chemical Profile and Calculation of Nitrogen-to-Protein Conversion Factors for Five Tropical Seaweeds. Am. J. Plant Sci., (2), 287-296.

Fathy, A. A. (2007). Evaluation of nutritional composition of some attached and drifted marine algae from Alexandria, Egypt. Egypt. J. Phycol., 8:131-141.

Fong, P.; Donohoe, R. M. and Zedler, J. B. (1994). Nutrient Concentration in Tissue of the Macroalga Enteromorpha as a Function of Nutrient History: An Experimental Evaluation Using Field Microcosms. Mar Ecol-prog Ser., 106(3): 273-281. 
Fujita, R. M.; Wheeler, P. A. and Edwards, R. L. (1989). Assessment of macroalgal nitrogen limitation in a seasonal upwelling region. Mar Ecol-prog. Ser., 53: 293-303.

Granéli, E.; Weberg, S. and Salomon, P. S. (2008). Harmful algal blooms of allelopathic microalgal species The role of eutrophication. Harmful Algae, 8(1): 94-102.

Hach, C. C.; Bowden, B. K.; Kopelove, A. B. and Brayton, S. T. (1987). More powerful peroxide Kjeldahl digestion method. J. Assoc. Off. Anal. Chem., 70: 783-787.

Hernandez, I.; Fernandez-Engo, M. A.; Perez-Llorens J. L. and Vergara, J. J. (2005). Integrated outdoor culture of two estuarine macroalgae as biofilters for dissolved nutrients from Sparus aurata. J. Appl. Phycol., 17(6): 557-67.

Hernandez, I.; Peralta, G.; Perez-Llorens, J. L. and Vergara, J. J. (1997). Biomass and dynamics of growth of Ulva species in Palmones River estuary. J. Appl. Phycol., 33: 764772.

Hosny, Sh. (2016). Ecological and Physiological Studies on the Interaction between Macroalgae and Phytoplankton off Alexandria Mediterranean Coast (Egypt). Thesis (PHD), faculty of Science, Tanta University.

Ismail, A. G. (2017). Biochemical composition of some Egyptian seaweeds with potent nutritive and antioxidant properties. J. Food Sci. Technol (Campinas), 37(2): 294-302.

Jones, D. B. (1941). Factors for Converting Percentages of Nitrogen in Foods and Feeds into Percentages of Protein, USDA (US Department of Agriculture) Circular Series, 183:1-21.

Kasimala, M. B.; Mebrahtu, L.; Magoha, P.P. and Asgedom, G. (2015). A review on biochemical composition and nutritional aspects of seaweeds. Carib. J. Sci. Technol., 3:789-797.

Kim S.; Park, S.R.; Kang, Y.H.; Kim, G.Y.; Lee, K. S.; Lee, H. J.; Nam-Il Won and Kil, H. J. (2014). Usefulness of tissue nitrogen content and macroalgal community structure as indicators of water eutrophication. J. Appl. Phycol., 26(2): 1149-1158.

Labib, W.; Abou Shady; Laila, A. M.; El Shafaay, Sh. M. and Hosny, Sh. (2015a). Ecological studies of macroalgae in Alexandria waters. Egypt. J. Exp. Biol., 11(2): 169 180.

Labib, W.; El-Dahhar and Diab, M. (2015b). Biochemical analyses of the green seaweed of Ulva fasciata from Alexandria coastal environments. J. World Aquacult. Soc., 10(2): 99117. 
Lilliesköld, S. J. and Erik, M. (2009). Tissue Nutrient Content in Ulva spp. (Chlorophyceae) as Bioindicator for Nutrient Loading Along the Coast of East Africa. Open Environ Biol. Monit. J., 2:17-11.

Lin Hsing-Juh and Jang, H. J. (2004). Factors affecting macroalgal distribution in a eutrophic tropical lagoon in Taiwan. Mar. Biol., 144(4): 653-664.

Lobban, C. S. and Harrison, P. H. (1994). Seaweed Ecology and Physiology, Cambridge University Press, ISBN 0-521-40897-0, New York.

Lourenço, S. O.; Barbarino, E.; De-Paula J. C.; Pereira LODS and Marquez, U. M. (2002). Amino acid composition, protein content and calculation of nitrogen-to-protein conversion factors for 19 tropical seaweeds. Phycol. Res., 50:233-241.

Lourenço, S. O.; Barbarino, E.; Lavín, P. L.; Lanfer Márquez, U. M. and Aidar, E. (2004). Distribution of Intracellular Nitrogen in Marine Microalgae: Calculation of New Nitrogento-Protein Conversion Factors, Eur. J. Phycol., 39 (1): 17-32.

Lourenco, S. O.; Barbarino, E.; Nascimento, A.; and Paranhos, R. (2005). Seasonal variations in tissue nitrogen and phosphorus of eight macroalgae from a tropical hypersaline coastal environment. Cryptogamie Algologie., 26:355-371.

Lourenço, S. O.; Barbarino, E.; Nascimento, A.; Freitas, J. N. P. and Diniz, G. S. (2006). Tissue nitrogen and phosphorus in seaweeds in a tropical eutrophic environment: What a long-term study tells us. J. Appl. Phycol., 18:389-98.

Marinho, S. G. and Holdt, S. L. (2017). Nitrogen-to-protein conversion factor of seaweed varies with season. In Book of Abstracts Sustain 2017 [Sustain Abstract F-2] Kgs. Lyngby, Denmark: Technical University of Denmark (DTU).

Martin, S.; Clavier, J.; Chauvaud, L. and Thouzeau, G. (2007). Community metabolism in temperate maerl beds. II. Nutrient fluxes. Mar. Ecol-prog. Ser., 335:31-41

Martínez-Aragón, J. F.; Hernández, I.; Pérez-Looréns, J. L.; Vázquez, R. and Vergara, J. J. (2002). Biofiltering Efficiency in Removal of Dissolved Nutrients by Three Species of Estuarine Macroalgae Cultivated with Sea Bass (Dicentrarchus labrax) Waste Waters 1. Phosphate," J. Appl. Phycol., 14(5): 365-374.

Moustafa, Y. T. A. and Saeed, S. M. (2014). Nutritional evaluation of green macroalgae, Ulva sp. and related water nutrients in the Southern Mediterranean Sea coast, Alexandria shore, Egypt. Egypt. Acad. J. Biol. Sci., 5(1): 1-19.

Neill, G.; Barr, T.; Alwyn, V. and Rees (2003). Nitrogen status and metabolism in the green seaweed Enteromorpha intestinalis: an examination of three natural populations. Mar. Ecol. Prog. Ser., 249: 133-144. 
Pedersen, F. M. and Borum, J. (1996). Nutrient control of algal growth in estuarine waters. Nutrient limitation and the importance of nitrogen requirements and nitrogen storage among phytoplankton and species of macroalgae. Mar. Ecol. Prog. Ser., 142: 261-272.

Ramos, M. V.; Monteiro, A.C.O.; Moreira, R. A. and Carvalho, A. F. F. U (2000). Amino acid composition of some Brazilian seaweed species. J. Food Biochem., 24(1): 33-39.

Safinaz, A. F. and Ragaa, A. H. (2013). Effect of some red marine algae as biofertilizers on growth of maize (Zea mayz L.) plants. Int. Food Res. J., 20(4): 1629-1632.

Shuuluka, D.; Bolton, J. J. and Anderson, R. J. (2013). Protein content, amino acid composition and nitrogen-to-protein conversion factors of Ulva rigida and Ulva capensis from natural populations and Ulva lactuca from an aquaculture system, in South Africa. J. Appl. Phycol., 25(2): 677-685.

Strickland, J. D. and Parsons, T. R. (1972). A practical handbook of sea water analysis 2nd Ed. Bull Fish Res. Bd. Can., 167: 310 pp.

Tabarsa, M.; Rezaei, M.; Ramezanpour, Z.; Waaland, J. R. and Rabiei, R. (2012). Fatty acids, amino acids, mineral contents, and proximate composition of some brown seaweeds. J. Appl. Phycol., 48: 285-292.

Taylor, R. and Raven, J. A. (2003). Macroalgal growth in nutrient enriched estuaries: A biogeochemical and evolutionary perspective. Water Air Soil Poll., 3 :7- 26.

Villares, R. and Carballeira, A. (2003). Seasonal Variation in the Concentrations of Nutrients in Two Green Macroalgae and Nutrient Levels in Sediments in the Rias Baixas (NW Spain)., Estuar. Coast Shelf S., 58: 887-900.

Williamson C. J.; Perkins, R.; Voller, M.; Yallop, M. L. and Brodie, J. (2017). The regulation of coralline algal physiology, an in situ study of Corallina officinalis (Corallinales, Rhodophyta). Biogeosciences, 14: 4485-4498. 
" Corallina officinalis و Ulva fasciata " دراسة لتقييم محتوى النيتروجين والبروتين لكل من الطحبين واستنتاج معامل جديد لتعيين البروتين تحت ظروف البن بين بئية مختلفة

$$
\text { والمعهى القومى لبيب - شيماء حسنى البحار والمصايد، مصر. }
$$

Ulva " تهدف الدراسة الى تقييم الأختلاف الكمى الموسمي و المكانى لمحتوي النبتروجين والبروتين لكل من الطحلبين Corallina officinalis \& fasciata Ulva " الثاطئية للاسكندرية. اظهرت النتائج اختلافات جوهرية موسمية لكل من الطحبين ، وكذا بينهما، وتميز طحلب ودئ

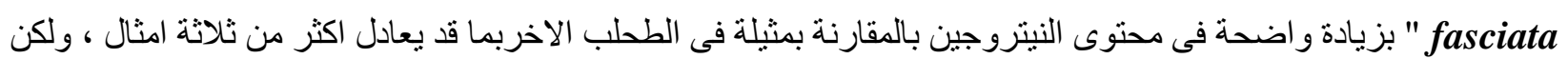
لا يمكن تحديد طراز معين عند الاستجابة للزيادة فى تركيزات الاملاح الغذائية. تقترح الدراسة امكانية استخدام وتطبيق المحتوى النيتروجينى كمؤشر احيائى فى المناطق ذات المستوى المرتفع فى نركيزات الاملاح الغذائية. تقدم الدراسة معاملا جديدا لتقدير البروتين لكل من الطحبين اعتمادا على تركيز ات النيتروجين ، وكذا مقارنات بما سبق نشرة. 